\title{
Housing Finance and Mortgage-Backed Securities in Mexico
}

\author{
Luisa Zanforlin and Marco Espinosa
}





\title{
IMF Working Paper
}

\author{
Monetary and Capital Markets Department
}

\section{Housing Finance and Mortgage-Backed Securities in Mexico}

Prepared by

Luisa Zanforlin and Marco Espinosa ${ }^{1}$

Authorized for distribution by David S. Hoelscher and Carlos I. Medeiros

April 2008

\begin{abstract}
This Working Paper should not be reported as representing the views of the IMF. The views expressed in this Working Paper are those of the author(s) and do not necessarily represent those of the IMF or IMF policy. Working Papers describe research in progress by the author(s) and are published to elicit comments and to further debate.

This paper reviews the Mexican experience with the securitization of residential mortgages. It highlights the key legislative and institutional reforms leading to the development of primary and secondary mortgage markets and reports the main features and valuation practices of the RMBS markets. The paper identifies areas warranting close attention to improve the outlook for the Mexican RMBS market and draws some lessons from the recent U.S. subprime mortgage market problems.

JEL Classification Numbers: O16; G21.

Keywords: Mexico; Housing Finance; Mortgage-Backed Securities; RMBS.

Author’s E-Mail Address: mespinosa@imf.org, lzanforlin@imf.org

\footnotetext{
${ }^{1}$ The authors would like to thank David Hoelscher, Carlos Medeiros, Steve Phillips and David Robinson for helpful comments and suggestions, to Graham Colin-Jones for helpful editorial comments and Claudia Pescetto for her able research assistance. Special thanks to Alan Elizondo and Oscar Grajales Herce in Mexico's Sociedad Hipotecaria Federal for very informative and candid communications.
} 
Contents

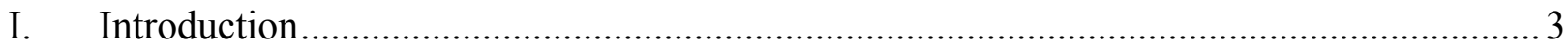

II. A Brief Review of Housing Finance in Mexico .................................................... 3

III. Reforming Institutions: The Foundations for Private Mortgage Markets ........................ 6

IV. The Mexican Way: From FOVI to HiTo ............................................................. 11

A. Securitization and Rise of the Mexican RMBS Market......................................... 14

V. Past lessons and Future Challenges ............................................................... 20

Boxes

1. Brief Chronology of Important Events in the Housing Finance Sector.............................5

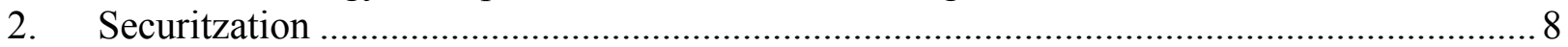

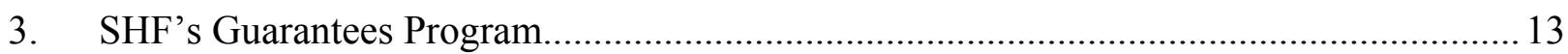

4. Main Characteristics of Mexican MBS Issues ......................................................... 19

Figures

1. Latin American Local Issuance of Securitized Assets 2006......................................... 15

2. Mexico: Domestic Market Private Debt Issues by Structure ........................................... 15

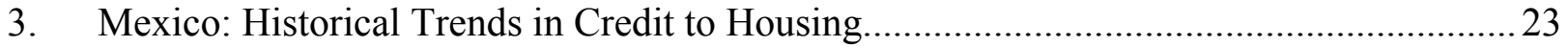

4. Mexico: Structure of Housing Finance, 2000-2005 ................................................ 24

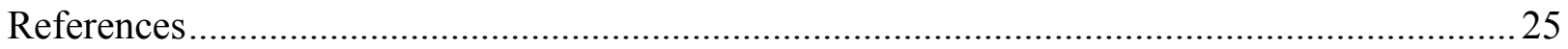




\section{INTRODUCTION}

Widespread household access to home finance has long been a goal of governments in Mexico. For generations, the Mexican approach focused primarily on redistributive schemes, implemented through state-sponsored housing funds, which were notorious for their inefficiency and poor governance. During the first part of the 1990s, the privatization of the banking sector led to very rapid growth in mortgage loans, but the sharp increase in interest rates following the1994 Tequila crisis contributed to record defaults and the near-collapse of the banking sector, followed by a long period of lending retrenchment.

Current efforts to develop the mortgage markets are built on a more solid foundation. Since 2001, the Mexican authorities have focused on developing the framework and infrastructure to support primary and secondary mortgage markets; in contrast to previous initiatives, the new approach places emphasis on market mechanisms, such as private mortgage insurance, and improvements in housing repossession procedures and the property registries. Both the primary and secondary mortgage markets have been developing in recent years and remain a work in progress as the government continues to adapt best international experiences to Mexican circumstances.

The paper tracks and highlights the key legislative and institutional reforms leading to the development of primary and secondary mortgage markets in Mexico and reports the main features and valuation practices of the RMBS markets. The paper identifies areas warranting close attention to improve the outlook of the Mexican RMBS market and draws lessons from recent developments in secondary mortgage markets. The remainder of the paper is organized as follows. Section II traces the experiences of housing finance mechanisms over the past three decades and the historical landmarks that led to the current structure of the institutions providing housing finance in Mexico today. Section III reviews the recent reforms in the institutional framework enabling new instruments for housing finance to emerge and contrasts them with the experiences in other countries. Section IV describes the roles and the functioning of the different institutions providing housing finance and the recent developments in the local market for mortgage-backed securities. Section V concludes by identifying possible developmental hurdles and providing policy recommendations.

\section{A Brief Review of Housing FinAnCe in MeXico}

Over the years, government sponsored financing of low-income housing has been channeled through multiple institutions (see also Box 1):

- In 1933, the development bank Banco de Obras Publicas (BANOBRAS) was created to finance low-income housing.

- In 1954, Fideicomiso del Fondo Nacional de Habitaciones Populares (FONHAPO) was created with a similar purpose. 
- In 1963, a government trust fund Fondo de Operación y Financiamento Bancario de la Vivienda (FOVI), operating within the central bank, was created to provide low interest mortgages for low to moderate income households. FOVI was funded by the central bank and the World Bank and operated as a second-tier bank, providing funding and guarantees (up to 45 percent of loss-given default) to the banks extending mortgages to targeted households and low-cost housing developers.

- In 1972, Instituto de Fondo Nacional de la Vivienda para los Trabajadores (INFONAVIT) and Fondo de la Vivienda para los Trabajadores al Servicio del Estado (FOVISSTE) were created as government-sponsored construction and housing development funding agencies. They have been funded by a mandatory contribution of 5 percent of gross wages. For decades they have been the workhorse of government-sponsored low-income housing finance. Indeed, INFONAVIT still has a large presence in the primary mortgage market_about half of the market (see below) (Figure 1). ${ }^{2}$ However, for years INFONAVIT was known for its lax collection practices and poor governance.

Directed lending and interest rate caps were popular credit allocation tools deployed in the late 1960 s and 1970 s as a means to secure private mortgages. Six percent of total bank credit had to be directed to housing finance at fixed or capped nominal interest rates. The oil shocks of the 1970s led to high inflation, negative real interest rates and large portfolio losses for banks, contributing to the 1981 banking crisis. The banking sector was nationalized in 1982 and the banking losses were absorbed by the government.

In the early 1980s, government securities crowded out private credit instruments, including mortgages. During the high inflation period of the early 1980s, banks were authorized to issue "dual index mortgages" (DIM) — which allowed negative amortization of the inflation-induced erosion of purchasing power. ${ }^{3}$ However, the 6 percent minimum credit allocation to housing lending remained a binding constraint for banks which did not increase credit to the sector. Government securities represented 70 percent of banks' total assets.

The re-privatization of the banking sector in the early 1990s did not immediately stimulate a private mortgage market. DIM mortgages faded away because of the continuous erosion in households' purchasing power, the consequent rapid increases in outstanding loan balances and associated increases in banks' credit and market risks.

\footnotetext{
${ }^{2}$ The federal government contributes to INFONAVIT's capital as stipulated in its charter (Ley del INFONAVIT).

${ }^{3}$ The payments on the DIMs were linked to the minimum wage index (VSM) and the difference between the changes in the minimum wage index (VSM) and the consumer price index was tagged to the outstanding principal (negative amortization).
} 
Furthermore, the 1980s' experience with mortgage defaults reinforced banks' cautious attitude towards the mortgage market.

By 1993, the introduction of legal reforms, inflation-indexed mortgages and benign international liquidity conditions led to a rebirth of a private mortgage market. In 1992 legal reforms were introduced to modernize housing deeds. At the same time, the country experienced a surge in capital inflows, stimulating a rapid growth in mortgage lending. Between 1989 and 1994, total bank credit to the private sector increased from close to 13 percent of GDP to more than 50 percent of GDP, while bank mortgage lending jumped from 1.3 percent of GDP to 2.4 percent of GDP (some 4.7 percent of total bank credit, compared with 10 percent in 1989).

The sharp interest rate spike in the aftermath of the Tequila crisis triggered a wave of bank mortgage defaults. The majority of mortgage lending in the early 1990s had adjustable interest rates. After the crisis, interest rates climbed to 74 percent, leading to massive defaults and a public sector bank bail-out. As part of a restructuring effort, mortgage loans on banks' balance sheets were registered in an alternative payment index, the UDI, which was a unit of measure that averages inflation over the past 15 days. Outstanding floating rate and dollar denominated loans were converted to long-term loans in UDIs that carried a fixed real interest rate, while the inflation component was capitalized.

After the crisis, commercial banks relinquished almost entirely the origination of real estate mortgages to non bank financial institutions and public sector entities. In 1994 non-bank financial intermediaries that specialized in real estate mortgages (Sofoles) were created, with their core market consisting of low income households. As non-deposit taking

\section{Box 1: Brief Chronology of Important Events in the Housing Finance Sector}

1933 BANOBRAS was created as the first public housing institution.

1954 FONAHPO

1963 FOVI

1972 INFONAVIT and FOVISSTE created as government-sponsored private and public (respectively) workers' housing funds

1982 Nationalization of the banking system

1986 Institution of the DIM mortgages

1986 Institution of FOBAPROA (now Ipab), the deposit insurance scheme

1988 Deregulation of interest rates

1989 Re-privatization of the commercial banking system

1989 Abolishment of the quantitative lending requirements and of the interest rate controls.

1991/2 Re-privatization of the banking sector.

1992 Reforms in FOVI and INFONAVIT and the public housing subsidy system.

1994 Creation of SOFOLES non bank financial institutions licensed to lend to particular sectors for specific types of activity.

2000 Amendments to the General Law on Securities and Credit.

2001 SHF commences operations.

2002 Law on Guaranteed Credit.

2003 First RMBS issued. 
institutions, Sofoles' main source of funding was FOVI, which also acted as their supervisor and determined the underwriting and service requirements. Since the second half of the 1990s, Sofoles have become the main issuers of private mortgages. Efforts were also made to step up and improve the efficiency of INFONAVIT's activities, and as noted by Gwinner (2006), INFONAVIT has substantially improved its management, operations, and corporate governance. ${ }^{4}$ Recently, it has also widened its cooperation with the private sector though the program "Apoyo INFONAVIT." The program allows its members to leverage their INFONAVIT savings to obtain market-based mortgage finance. INFONAVIT also has securitized portfolios, although the securitizations have been expensive, requiring 18 23 percent subordination of the residual certificate for the senior certificates.

Traditionally, bank mortgage activity concentrated on the middle to upper income segments. Lower income segments were considered high credit risk and banks were reluctant to invest on origination platforms. However, Sofoles' success in originating and servicing low-to-middle income mortgages led some commercial banks to acquire some of the largest Sofoles. New bank lending represented 7 percent of residential mortgages in 2005 compared to only 0.2 percent in 2000 .

\section{Reforming Institutions: The Foundations for Private Mortgage Markets}

\section{A series of obstacles hindered the emergence of a primary private mortgage market} until the mid-1990s. These included directed lending practices, a lack of comprehensive borrower credit history records that would allow the estimation of historical default probabilities; and the absence of a framework for the sharing of available borrowers' credit information across banks. The only credit information sharing mechanism until the early 1990s was the public credit registry (SENICREB) operated by Bank of Mexico, but its use in supporting credit decisions was limited. In addition, there was significant uncertainty and lengthiness associated with the home repossession process. Foreclosures in Mexico could take up to five months to be filed for and two years for a foreclosure sale to be ordered. Even then, owners would not be liable for any remaining amount which would remain due in the event the foreclosed property sold for less than the lien amount owed.

\section{There were also significant obstacles to the development of a secondary mortgage} market through securitization (Box 2). As pointed out by, for example, Barry, Castaneda and Lipscomb (1995), there was a lack of standardization in mortgage loans, with each commercial bank offering its own lending terms, and making it impossible to pool them to be securitized. Furthermore, there was no government agency or public institution in charge of directing or overseeing loan standards. The lack of a comprehensive credit history created difficulties in estimating not only default probabilities, but also pre-payment probabilities.

\footnotetext{
${ }^{4}$ FOVISSSTE's operational improvements, though not trivial, are much less significant than INFONAVIT's.
} 
Moreover, the legal framework for the sale of real estate assets necessary for a securitization to take place was particularly cumbersome as, under Mexican law, the transfer of real estate titles, such as mortgages, had to be registered with a central registry office, which was a lengthy and costly process given the high fixed notary fees. In addition, by law, during a sale of real estate assets, borrower notification was required, which tended to delay the process significantly. Also, when a lien is registered on the property to secure a mortgage loan, such lien did not give absolute seniority to the mortgage originator. In fact, the law specifically identified categories of creditors whose claims will be considered senior to those of a mortgage lender for the sale amount of a property. For example, municipalities have seniority over other lenders for any tax amounts due and so do employees for any wages unpaid. Finally, while real estate guarantee trusts existed prior to 2001 as legal entities that functioned as a special purpose vehicle (SPVor SPE) in Mexico, their main objective was to serve as a real estate trustee and were not allowed to issue debt (a key element for securitization). 


\section{Main elements}

\section{Box 2. Securitization}

Mortgage securitization is a technique which allows mortgage issuers to access fresh funding and to transfer market and credit risk imbedded in their existing loans. In a securitization operation, a mortgage originator sells its loan portfolio to an independent special purpose company or vehicle (SPE or SPV). The SPV's funding comes from its issues of securities to capital market investors. The cash flow generated from the interest and principal re-payment of the loans is used to service the securities backed by mortgages (mortgage-backed securities or MBSs), and the mortgages act as their collateral.

There are a number of legal steps and infrastructure requirements for an efficient securitization of mortgages (see Lea et al. 2004). First, the loans in the pool to be the securitized should have uniform characteristics, including terms of the loan, documentation, credit quality and performance history. Second, mortgage foreclosure procedures, which ensure protection of creditor rights, must be relatively speedy and of low cost to ensure high creditworthiness of the securities. In addition, mortgages must be fully transferable, as the SPV needs to acquire full rights over the receivables from the loans and its claim on the collateral must be senior to any other claim. This is necessary to ensure that the creditors of the originator's bank will be voided from any claim on the collateral of the securitized loan in the event the originator were to default. Also, the tax system must be designed to allow for the transfer of assets to be securitized without generating costs in the mere swap of funds from the loan originator to the SPV issuer.

The SPV must be an entity of "high credit quality." For example, in the U.S .SPVs must be capitalized, to ensure creditworthiness to the securitized issues, and legal empowered to issue securities. These SPVs also perform a mortgage service, for which they are paid between 0.25 and 0.5 percent of the loan balance.

The pricing of MBSs should reflect the historical patterns of re-payments and defaults in the areas where the mortgage loans were originated. Therefore, data on default rates and on pre-payment history (particularly in the absence of pre-payment penalty), are crucial for an accurate pricing of the MBSs. In this respect, not only the collection of such data but also an agreement that financial institutions will share credit information will be necessary for an MBS market to develop.

\section{Main Benefits}

By securitizing the mortgage loans, mortgage originators can book the proceeds from the sale of the mortgages immediately as cash. Thus, the operation generates funding for new lending activities. By transforming the loans in securities that can be held in investors' portfolios, mortgage originators will also be able to access a broader pool of private sector savings. By removing the loans from the balance sheets, mortgage originators will achieve a diversification of credit and market risk. In addition, remaining mis-match in assets and liabilities's cash flows and any credit risk will be removed from the mortgage originator and dispersed across market investors. Finally, the regulatory capital requirements of the mortgage originators are typically reduced as the loans are taken off their balance sheet.

In addition, the securitized bonds backed by mortgage loans (MBSs) can be structured in different ways to either achieve a certain diversification of risk or to cater to the investment base. The most commonly found securities which are backed by mortgage loans are socalled pass-through securities or tranched issues.

Pass-through securities will present exactly the same characteristics as those of the underlying loans in terms of coupon, term, duration and market risk. In particular they will also have the same pre-payment risk as the underlying loans and all market and credit risk will be passed on to the investors.

Tranched issues are paid sequentially according to seniority in such a way that the higher tranches receive the flow of pre-payments first, and thus have shorter duration and the lowest risk, with the lower tranches being redeemed only after the higher tranches have been redeemed in full. This presents investors with choices on the expected duration or risk of the security to acquire. It is typical that MBSs will aim for an investment grade rating so as to be marketed to institutional investors. Since mortgage originators may not have very high credit ratings, mortgage securitization transactions typically require some form of credit enhancement in order to achieve an investment grade rating or, a rating higher than the originator bank. The enhancements can either be included in the structure of the securities, so that, for example, the principal of the underlying pool of loans is greater than the principal value of the securities issued (overcollaterization) or provided by a partial guarantee provided by a third party. 


\section{Financial Sector Reforms to Boost Private Mortgage Markets}

\section{Significant efforts have been made to overcome the obstacles to financial sector development in general and housing finance in particular. A number of legislative and regulatory efforts were directed to improve the ability of financial institutions to achieve creditor information and to improve contract enforcement and creditor rights by clarifying and streamlining foreclosures and repossession process while developing the legal framework for guarantee trusts to be operational in the mortgage securitization process.}

In the first place, the banking secrecy reform enabled banking institutions to share information on customer credit operations, providing a strong impetus to the credit reporting industry. A shakedown in the late 1990s of the few existing private credit bureaus led to the emergence of one dominant entity (Buró de Crédito) that is owned by financial and non-financial institutions. The enactment of a law in 2002 (amended in 2003) to regulate its activities and protect privacy rights, resulted in more than 1,000 institutions feeding the databases of Buró de Crédito with positive and negative information on more than 64 million individual accounts and 4 million company accounts. Banks and other lenders can obtain real-time data on customers that, in combination with their own proprietary information, allow them to better differentiate borrower risk (calibration of scoring models) and expand credit.

\section{Subsequently, in 2000, a new Securities Law together with the Law on Guaranteed} Credit $^{5}$ allowed guarantee trusts (fideicomisos) to act as a full-fledged Special Purpose Vehicle (SPV). ${ }^{6}$ Creditors of trusts were granted rights over loan collateral with no exclusion: this increased the legal protection of creditors' rights over trusts with respect to, for example, mortgages (which are junior to other categories of creditors). In addition, foreclosure procedures were simplified in the case of trusts because the administrators of the trusts (trustees) had the right to sell loan collateral in a public auction and without following a judicial foreclosure process. ${ }^{7}$ The new law also allowed financial institutions to both act as trustees and to be beneficiaries of the trust, so that banks and non-banks (Sofoles) may hold title to a property through a trust and, in the event that borrower fails to pay the credit, the trustees can foreclose on the loan through out-of-court-procedures. Financial institutions were also exempted from the registration requirements for the transfer of mortgage liens (if they continue to service the credits), thus further streamlining the procedures for

\footnotetext{
${ }^{5}$ Ley General de Títulos y Operaciones de Crédito.

${ }^{6}$ In Mexican law, the trust (fideocommisso) is a contract by which a person assigns a property to a special purpose, transfers the title of the property to a fiduciary institution to get the purpose done and appoints a beneficiary of the trust to receive the benefits.

${ }^{7}$ If there is no controversy in the process. If there is a controversy, then the trustees will have to undergo formal judicial process.
} 
securitization operations. ${ }^{8}$ The new Securities law introduced a new market instrument, the so-called "certificados bursatiles" or ceburs, which were by nature sufficiently flexible to also be used as a vehicle for securitized issues. The law also streamlined the formalities for the transfer of mortgage liens by exempting financial institutions from the registration requirement as long as they continued to service the credits themselves.

\section{In 2003, further legislation ${ }^{9}$ established standard financial clauses for every mortgage} contract and required that loan information should appear in a standardized format so as to allow comparison across different contracts. The law also provided that the mortgage originator, in case of an anticipated total payment, would assign all the rights derived from the credit to the payer. This feature introduces prepayment risk to the holders of mortgagebacked securities just as in the U.S. case. (Caloca-Gonzalez 2006). The regulations for credit bureau operations were also further revised to improve timeliness of data and increased depth and quality of borrower information.

\section{Mexico has drawn from the international experiences with secondary mortgage markets}

As in the U.S., the Mexican secondary market was launched with the support of government sponsored initiatives. In the U.S., the secondary mortgage market developed through government sponsored agencies. However, SHF departed from the U.S. scheme where government sponsored agencies buy mortgages from loan originators who comply with certain standards, pool them together and use them to back their issues of securities which are serviced with the proceeds from the underlying mortgages. In Mexico, originators have been issuing directly mortgage-backed securities in the market and benefiting from credit enhancements provided by SHF in the form of financial guarantees to mortgage originators meeting SHF's origination standards.

As in the U.S., the use of credit enhancements by private mortgage issuers have been used to boost the ratings of mortgage-backed securities beyond their originator's rating. Recently, in Mexico, as in the U.S., private credit enhancements have also been provided by global companies such as MBIA, FIGC, AIG, Genworth and AMBAC.

Some features of the Danish model have also attracted significant attention in Mexico. The most important feature of the Danish secondary mortgage market has been its high liquidity. The mortgage bonds are highly liquid because the large pools of securitized loans offer uniform characteristics such as coupon, rate of amortization, and loan to value ratios. Liquidity is also supported by a market-making scheme where ten commercial banks trade all

\footnotetext{
${ }^{8}$ If there is no controversy in the process. If there is a controversy, then the trustees will have to undergo formal judicial process.

${ }^{9}$ Ley de Transparencia y de Fomento a la Competencia del Crédito Garantizado (2002).
} 
open-for-issuance mortgage bonds at a common price. Issuance and trading is done through the Danish Central Depository Institution (VP) and the pass-through bonds have the same characteristics of the underlying pool of mortgage loans (see Frankel et al.) ${ }^{10}$. The adoption of VP's technological platform in Mexico is expected to contribute to help liquidity and smooth trading of the RMBS market. As in the U.S., mortgages in Denmark, and Mexico have a penalty-free prepayment clause, subjecting the holder of the mortgage to prepayment risk. However, in Denmark, unlike in the U.S., regulation requires a strict matching of cash flows between the underlying loan and bond servicing flows. The result is that prepayment risk is held by investors who, relative to the U.S. housing agencies, accept larger fluctuations in the duration measures of their bond portfolios (see Frankel et al. ). As in the U.S., the Mexican scheme has no provisions to fend against prepayment risk.

\section{The MeXICAN WAY: From FOVI to HiTo}

\section{In 2001, Sociedad Hipotecaria Federal (SHF) was created with a view to developing the} secondary mortgage market. Originally, the SHF was seen as playing a role similar to that of the Federal Housing Agencies (FHA) in the U.S., such as Fannie Mae and Ginnie Mae, providing partial mortgage credit guarantees and acting as a second-tier bank for Sofoles. ${ }^{11}$ However, the SHF was designed to gradually reduce its direct second-tier bank role, shifting toward supporting financial institutions in issuing mortgage-backed securities (MBSs) directly in the capital markets.

\section{SHF began selling partial financial guarantees and mortgage insurance to Sofoles (Box}

3 ). The main guarantee programs consisted in a partial financial guarantee (Garantia de Pago Oportuno or GPO) which provides protection for timely payment of the obligation of the MBSs, similar to a credit line; and a default payment guarantee (GPI) or mortgage insurance ${ }^{12}$ which pays the financial intermediary or the trust up to 35 percent $^{13}$ of the

\footnotetext{
${ }^{10}$ However, in Denmark, the pre-payment risk is reduced by a feature of the mortgage loans whereby a borrower can deliver a bond in lieu of the mortgage payment. This feature has the advantage that the purchase of the bonds on the market by the borrower does not cause a pre-payment event. It also has the advantage that when mortgage bonds are trading at a discount, the borrower can take advantage of such discount to repay his or her mortgage. This also implies that mortgage investors benefit from early repayment of mortgage loans for bonds trading below par (and thus can re-invest their proceeds at a higher interest). In addition, mortgages are transferable among borrowers which makes pre-payment risk in Danish mortgage securities less exposed to demographic factors than in the U.S. securities (Frankel et al. 2004). This feature of the Danish model is not being adopted in Mexico.

${ }^{11}$ Direct SHF financing of Sofoles is to be discontinued in 2009 and, by 2013, SHF is to be a self-sufficient agency. The latest data available show that, as of the end of 2005, the agency held close to US\$15 billion in direct home loans, up from US\$13 billion in 2002.

${ }^{12}$ Mortgage Insurance is a mechanism to transfer the credit risk from mortgage loans to an insurance company at relatively low down payments. In various countries, such as the U.S. Canada, Australia and Hong Kong, this insurance has been successful in promoting a mortgage market with reduced down payment (For example, mortgage insurance can be structured to reduce the expected value of the loss on the loan for the bank. For
} 
outstanding balance of the mortgage loan, plus interest thereon, and unpaid service and insurance fees, after a mortgage loan is delinquent for six consecutive months. Such guarantees are designed to provide bond insurance to MBS investors. ${ }^{14}$

\section{SHF also offers a swap to meet the housing finance needs of low to medium-income} households. SHF sells a swap of UDI for minimum salary payments. This allows borrowers to make payments in multiples of minimum salaries against UDI denominated mortgages. The structure of the mortgage for the borrower is similar to that of earlier DIMs. In order to hedge against losses in the event that UDIs rise above the minimum wage, SHF sells the long VSM position to FOVI which, eventually, would be bearing such losses.

example: given a 5 percent down payment, and a 15 percent mortgage insurance, the bank has at-risk 80 percent of value of the loan).

${ }^{13}$ Initially it was 25 percent and it was increased in April 2004.

${ }^{14}$ The program of partial financial guarantees, which are paid for by the securitizing agents, relieves the market from the liquidity risk associated with shortfalls in principal and interest. The mortgage insurance guarantee provides a "first loss" position with respect to losses due to default of the underlying loans. Since the presence of the guarantees lowers the probability of a principal loss for the investor and ensures the timely payment of bonds until foreclosure, such guarantees effectively increase the credit quality of securitized loans. Through financial guarantees, the credit quality of securitized loans can well exceed the credit quality of the originating institution. Effectively, the guarantee scheme is supporting increased securitization activity by originating institutions as they can sell the high-quality part of the credit to the market while not increasing their own exposure to household sector risks. 


\section{Box 3. SHF's Guarantees Program}

Different kinds of guarantee programs are directed both to mortgage borrowers and to lenders seeking to securitize mortgage portfolios. In general, SHF sets specific criteria to qualify for such guarantees.

\section{Guarantees for mortgage borrowers}

- $\quad$ A swap of UDI for minimum salary payments (VSM). This swap allows borrowers in UDI-denominated loans to reduce the risk of mortgage debt by transforming payments in multiples of minimum salaries. The structure of the mortgage for the borrower is similar to that of a loan in UDIs. However, the risk that an increase in UDIs is higher than the increase in the minimum wage is taken over by SHF upon payment of a fee.

\section{Guarantees for lenders}

- A default payment guarantee (GPI) or mortgage insurance ${ }^{1}$ will pay to the relevant financial intermediary or the trust up to 35 percent $^{1}$ of the outstanding balance of the mortgage loan, plus interest thereon, and for unpaid service and insurance fees, after a mortgage loan is delinquent for six consecutive months and foreclosure takes place. The fee for the GPI is paid for by the borrower, through the financial intermediary.

- A mortgage insurance scheme (GI) which insures the lender for up to 70 percent of the outstanding balance of the mortgage loan, plus interest thereon, and for unpaid service and insurance fees for certain loans, including those that contain an up-front subsidy from the government.

\section{Financial Guarantees for RMBS issuers}

- A timely payment partial guarantee program, Garantia de Pago Oportuno (GPO), is designed to provide assurance of timely payment of principal and interest up to 85 percent of the outstanding balance of principal and interest for those loan portfolios that comply with certain requirements. (However, the maximum protection acquired by any institution has been 25 percent so far.) Timely payment guarantee is a credit enhancement at the deal level of the structure, and is similar to a credit line. If the trust does not have sufficient cash to make a given payment, the line of credit can be drawn to pay both interest and principal. Once the line of credit is repaid, it can be drawn down again, if the need arises. The fee to the provider of the GPO is part of the expenses of the trust.

To qualify for SHF's support, mortgages have to be originated and underwritten following specific requirements-among others, debt-to-income ratios, loan-to-value ratios, property type and values, and reporting requirements for the financial intermediaries. Should a loan not comply with the eligibility criteria, the trust would have to reimburse SHF for any payment made under the guarantee for that specific loan.

The criteria set by SHF to condition the sale of GPI or GPO have the important effect of inducing standardization in mortgage products. In particular, mortgages have to meet 
debt specific income ratios, loan to value ratios, property type and values, and reporting requirements for the financial intermediaries. In addition, SHF reviews all the loans to be securitized before awarding GPO guarantees.

While initially SHF was the only provider of mortgage insurance and financial guarantees, recently private sector financial guarantee providers have entered the market. Regulatory changes in the insurance sector passed in 2006 led to the licensing of two foreign mortgage insurance companies to operate in Mexico. Financial guarantee providers such as Ambac, Genworth FMO, IFC and most recently MBIA, have been recently competing with SHF in the provision of these guarantees.

Future plans of SHF include the development of a comprehensive mortgage data base. SHF will oversee Mortgage Information Statistics (FIEH), which is designed to include borrower characteristics, house prices and loan payment history. All such information will become available to mortgage lenders, insurers and investors in securitized loan pools and will provide an essential tool to enhance transparency and efficiency in the mortgage markets. However, this project was not fully operative at the time of this paper was written.

\section{Recently, Hipotecaria Total (HiTo) was set up with the goal of expediting the} securitization process. Although mortgage securitizations can be carried out through a Trust, the process can take up to a month. In an effort to expedite the process, the Danish central depository institution (VP), in collaboration with SHF, set up a technological platform in HiTo to launch a system that is open to any party interested in the securitization of a mortgage portfolio. HiTo allows the continuous interface of banks, Sofoles and the Mexican depository institution INDEVAL so as to expedite and reduce risks in the securitization process.

\section{A. Securitization and Rise of the Mexican RMBS Market}

\section{The structured finance market has experienced extraordinary growth since its} inception both in asset types and debt structures. Total issues of structured securities reached over US\$6 billion in 2006 - tripling in volume since 2004. ${ }^{15}$ Mexico has the largest issuance volume in Latin America. Early structured issues comprised primarily bridge loans for construction to developers; federal tax participation revenues (transfers from the federal government to states and municipalities); toll road receivables and consumer credit flows.

\footnotetext{
${ }^{15}$ Data according to Fitch. There were two operations in 2004 and 2005 identical in nature for US\$4.5 billion and US\$2.4 billion by Banamex and Banorte, respectively. However, the two operations, which concerned the securitization of a loan by IPAB (the deposit insurance agency), were only possible because of a legal loophole in the terms of the original loans which is not present in other loans by IPAB. Therefore, similar operations cannot be repeated, and therefore, excluded from the total for comparison purposes.
} 
Mortgage backed securities (MBS) based on residential mortgage loans (RMBS) made their first appearance in late $\mathbf{2 0 0 3}$ and by 2006 they had become the largest structured asset class, representing over 25 percent of total local structured issues. ${ }^{16}$ As of October 2007 there were over US\$6.4 billion RMBS issues outstanding in the Mexican bond market by seven different Sofoles, two banks and INFONAVIT.

Favorable global liquidity conditions and a growing local institutional investor base have supported the

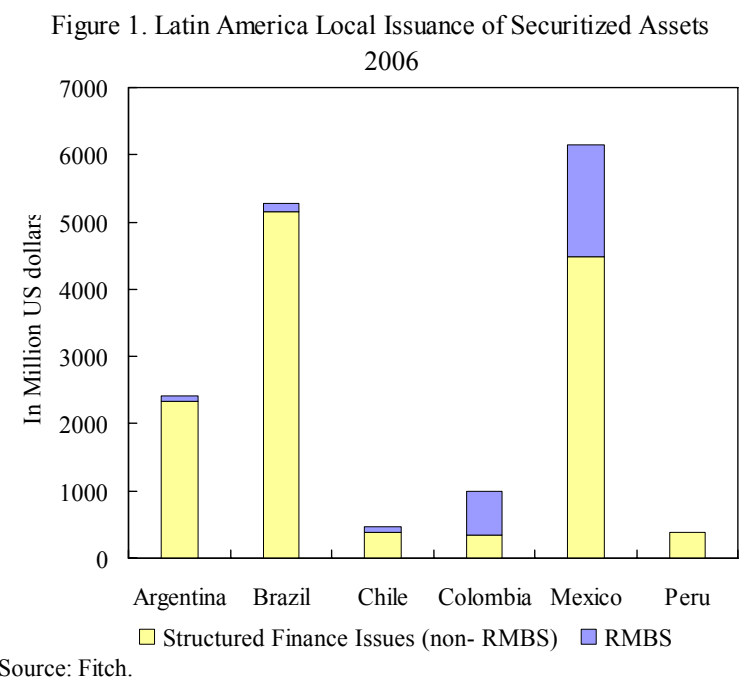
new structured issues. Securitized structures are particularly attractive to pension fund managers because they typically carry a high credit rating and long duration which matches well with their natural liability structure and prudential regulatory regulations.

The strong growth in RMBSs was supported by SHF. Those RMBSs that satisfy the loan origination criteria, which would make them eligible for SHF support through credit enhancements, are commonly referred to as Borhis ${ }^{17}$ in the local market. However there are also other types of mortgage-backed securities outstanding. In the case of Borhis, SHF offers support to

Figure 2. Mexico: Domestic Market Private Debt Issues by Structure

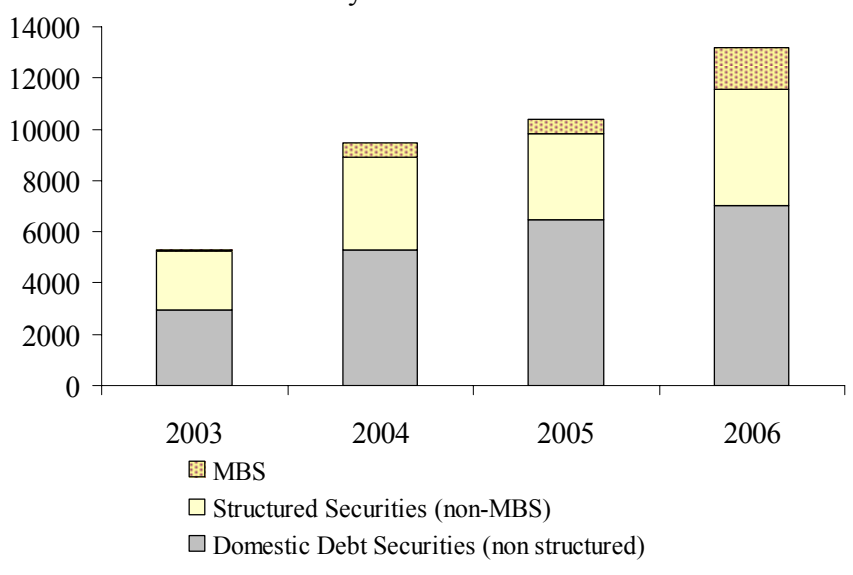
the liquidity of the issues by acting as "market maker" and thus committing to buy Borhis both in the primary and secondary markets. Under normal conditions, SHF buys at a price based on its own cash flow and computed according to a methodology based on certain prepayment and default assumptions.

\footnotetext{
${ }^{16}$ Data by Fitch.

${ }^{17}$ Bonos Respaldados por Hipotecas.
} 


\begin{abstract}
More recently, Mexico has adopted the Danish technological platform which enabled mortgage originators to start issuing RMBSs closer to the Danish ones. The important difference between these RMBSs and those previously in the Mexican market is that the existing series can be augmented by re-opening it during the first year up to a pre-established maximum and increasing the size of each issue in the market, thereby allowing it to achieve higher liquidity. ${ }^{18}$ A loan's monthly payments will cause some bonds to be withdrawn from the pool in the amount the loan pays down. These pass-through securities will be issued through the centralized agency, HiTo. The first re-openable MBSs, so-called "Borhis fungibles", made their appearance in late 2006.
\end{abstract}

\title{
Issuers and Investors
}

Sofoles were the first and by far the most active users of the new financial instruments, but INFONAVIT has quickly followed. As of October 2007, Sofoles accounted for 60 percent of total outstanding RMBS stock of issuances, while commercial banks represented around 5 percent of issues. This has been due, in part, to the structural decline in Sofoles' funding sources, together with the rising demand for housing credit, which gave strong incentives to Sofoles to securitize their portfolios. Following the success of the initial RMBS structures, INFONAVIT rapidly became one of the largest issuers in the market, and in October 2007 accounted for around 27 percent of the outstanding stock of RMBS issues in the market. Commercial banks' large deposit base had so far been sufficient to finance lending activities. However, in the course of late 2006 and early 2007 several banks entered the market and opened some of the largest issues outstanding (Box 5).

Local institutional investors dominate the market for structured issues. To date, the bulk of RMBS issues are held by domestic pension funds and insurance companies. As tranched issues appeared, institutional investor interest concentrated in the senior tranches. This strong demand reflects a number of factors:

- First, Mexican MBSs are typically denominated in UDIs ${ }^{19}$ and thus generate inflationlinked returns matching pension funds' liability structures (Box 5);

\footnotetext{
${ }^{18}$ Every fungible Bori structure has reopening periods ranging from one to three years.

${ }^{19}$ The UDI is a unit of account the value of which is updated daily and reflects the changes in the consumer price index. On the 10 and the 26 of each month the Bank of Mexico publishes the UDI's value for the next fifteen days. On the 10 and the $26^{\text {th }}$ day of the month the change in UDI value will be equal to the change in the consumer price index in the previous 15 days of the month, the value for the days between the 10 and $26^{\text {th }}$ will be computed by distributing the total increase in the CPI across the number of days in the period. The UDI had a value of 1 on April 4, 1995 (as of 4/2007 approximately 3.85).
} 
- Second, by enhancing the credit profiles through financial guarantees, overcollateralization, and junior tranches, structured issues achieve an investment grade credit rating that local issuers would otherwise not achieve;

- Third, structured issues carry slightly higher yields than the comparable government securities; and

- Finally, the terms of the underlying loans, together with those of the securing collateral, allow structured issues to have a relatively long duration with respect to other instruments in the local market, which tend to be concentrated on the short-end of the yield curve.

Subordinated tranches of MBS issues reportedly have had less appeal, but appetite for such tranches appears to have been growing recently. More recently, high liquidity in international markets generated some foreign investor interest for MBSs as securities with a relatively higher yield. Local mutual funds have also been attracted to them because of the yield pick-up they offer. However, in some cases, junior tranches have been reportedly retained by the originating institutions, thus preventing them from fully divesting their credit risk.

\section{Valuation and Rating}

In Mexico, there is a high degree of uncertainty surrounding the parameters used to model the cash flows from the RMBSs' underlying assets. In particular, there is a lack of comprehensive historical data on default rates, prepayment rates, and recovery rates and on the length of the foreclosure process. In addition, recent legislative reforms affecting the foreclosure process (as discussed above) may have altered the significance of the available historical information, so that most of the relevant parameters in the valuation process have to be assumed. ${ }^{20}$

The lack of historical and market data housing prices further complicates assessment of loan-to-value ratios and of the over-collateralization of portfolios. In principle, house values for mortgages in portfolios guaranteed by SHF must be formally appraised; however, most of the time, house prices for loan purposes have been supplied directly by the construction companies. The authorities are also aware of the need to deter fraudulent appraisals as these would compromise the valuation of RMBS, and the integrity of the investors' (e.g. pension funds') portfolios.

\footnotetext{
${ }^{20}$ For example, repayments rates are typically assumed to be constant, imputed either to the loan pool or to each single loan. While in Mexico typically there are no restrictions or penalties on prepayments, the cost of re-financing mortgages is high, thus prepayment rates have tended to be less sensitive to interest rates than in the U.S. Market reports suggest the constant pre-payment rate has been assumed at 5 percent, and indeed according to an SHF White Paper, historical experience with prepayments has been around this level.
} 
The government bonds denominated in UDIs (Udibonos) used as benchmark bonds for the pricing of the securities have been illiquid, complicating the price discovery process for the securities valuation in the RMBS market. These bonds were the only local UDIdenominated securities with a term structure relevant to RMBSs. However, historically, the Udibono market usually has been very illiquid (it is heavily influenced by pension funds that do not trade Udibonos actively).

Currently, the only source of information for RMBS prices in the secondary market are the local price vendors. ${ }^{21}$ The models used by these agencies to price the securities are not fully clear; however, SHF is working with the price vendors to improve practices. SHF is not required to buy the bonds at the prices announced by the vendors.

The valuation of RMBSs relies heavily on rating agencies' review process. High ratings make securities suitable for pension fund portfolios. Factors behind the high rating of the early Borhis, beyond SHF's partial financial guarantee, include SHF's incentives to Sofoles to issue loans with conservative loan-to-value ratios, mortgage insurance, and the UDI -VSM swap for all UDI-denominated loans. In more recent issues, since the junior tranches ${ }^{22}$ effectively provide an additional buffer for the senior tranches, the senior tranches have not needed a financial guarantee to attain an "AAA" rating on the local Mexican scale. Some issues which had a senior tranche with a total financial guarantee were rated "AAA" on the global ratings scale. Because the mortgages in most securitizations are covered by mortgage insurance for up to 35 percent of the losses, even the junior tranches still qualified for an " $A$ " rating. ${ }^{23}$ However, for the initial rating of the securities, rating agencies have tended to rely heavily on SHF's due diligence on the quality of the loan portfolio to be securitized. Furthermore, some have suggested that rating agencies should play a more proactive role in the rating review of RMBSs, as there are reports that downgrades to RMBSs occurred only after irregularities had become readily apparent.

\footnotetext{
${ }^{21}$ Price vendors are institutions created in Mexico because of the structural illiquidity of the private issues market. Such institutions are supposed to be independent and to provide price information for market operators.

22 Junior tranches are also referred to as "mezzanines."

${ }^{23}$ Local scale A is equivalent to BB- on the international scale.
} 


\section{Box 4. Main Characteristics of Mexican MBS Issues}

The main features of the MBSs in the market have reflected, to a large extent, the type of originating institution. MBS issues by Sofoles are typically denominated in UDIs and thereby are inflation-linked. The underlying loans are mostly standardized, and carry enhancements purchased through SHF or other insurers (see below). Issues originated by Infonavit ${ }^{1}$ tend to have underlying loans more diverse in nature, although, reportedly, all sharing the same duration of the structured paper that was issued. Typically the characteristics of INFONAVIT's loans depend on the borrowers' income level and the size of the house to be purchased. ${ }^{1}$ These issues carry no direct financial guarantees but include over-collateralization as a form of credit enhancement. Because INFONAVIT is a government-sponsored institution, there is a perception on the part of investors that these products also have an implicit government guarantee. Diversified MBS issues by commercial banks have emerged at a fast pace. Such issues are mostly structured to reflect the fixed peso characteristics of the mortgages extended by banks. Interestingly, not all of these RMBs carry mortgage insurance and guarantees offered by SHF. Instead, the enhancements in a number of commercial bank issues consist of extended liquidity facilities (or total financial guarantees) by large international insurance institutions and tranched structures to support the credit ratings.

Coupon: Interest rates on MBS issues have averaged between 5 to 6 percent in real terms. More recent issues have carried lower coupons reflecting both an easing of real rates in the economy and a compression in MBS spread vis-àvis their benchmark UDIbono bonds. While early issues carried a significantly higher spread (around 120-140 basis points) with respect to the UDIbono yield curve, the more recent ones which ranged around 80-90 basis points. Over time the spreads for Sofoles-issued MBSs have been compressed owing to the greater demand and higher liquidity of the market provided by SHF's activity on the secondary market. However, the compression in spreads also reflected changes in the structure of the RMBS, in particular, the increased use of mezzanine tranches as the market developed (see below). More recent issues have also benefited from a total financial guarantee (rather than just the partial GPO guarantee) on the senior notes which brought a further decline in issuance spreads to around 40-50 basis points above the UDIbono benchmark.

Term : RMBS term has ranged from 10 to 30 years with most of the most recent issues around 30 years. They carry the longest maturities available for a private (and public) sector security on the market. The typical term for other types of asset-backed issues in Mexico has been from five to seven years.

Credit Enhancements: Most of the issues by Sofoles are structured so as to comply with requirements to qualify for the SHF partial financial guarantee (GPO). The qualification requirements for GPO are that the holders underlying mortgages need to hold a UDIs-VSM swap and that underlying mortgages are covered by the mortgage insurance guarantee (GPI). There are also loan-to-value ratio requirements which cannot exceed 80 percent for UDIdenominated mortgages and 90 percent for peso-denominated loans. Most MBSs have over-collateralization (OC) implying that the value of the principal assets backing a certain issue exceeds the value of the security outstanding. The OC levels have been variable in the order of 0.8 up to 15 percent. In more recent deals, the initial collateralization has been close to 1.0 percent with the over-collateralization expected to build to a higher target value as the bond principal amortizes. Most recently, several issues appeared a total financial guarantee (so called full wrap), which covers 100 percent of shortfalls in principal and interest payments. Such guarantee is a liquidity guarantee that does not cover against losses due to default but ensures timely payment. However, the issues carrying such guarantee had a subordinated structure (see below) that would be the first to absorb the credit losses.

Structure: Given the absence of a market for below investment grade rated securities, early issues were singletranched with credit enhancements provided by SHF in the form of mortgage insurance (GPI) and a financial guarantee (GPO). A small equity position, typically around 4 percent was retained, and fully provisioned for, by the originator. More recently, issues have had a senior and a subordinated (or junior) tranche structure as typical in mature debt markets and a broader variety of credit enhancements. When issues are tranched, receipts are distributed by tranche seniority, i.e. accruing to the senior tranches first, while losses are distributed inversely. Because, in general, mortgages in these securitizations have mortgage insurance for the first 35 percent of the losses, junior tranches typically have still qualified for an A rating on a local scale. ${ }^{1}$ As the junior tranche, or mezzanine, effectively provides an additional buffer for the senior tranches, these tranches do not need a financial guarantee to attain a AAA local rating. Some senior tranched with a total financial guarantee (100 percent fullwrap) qualified for a AAA global rating. The senior tranches have represented about 80 percent of the portfolios while junior or "mezzanine" tranches have ranged between 3 to 12 percent. Equity positions between 4 and 8 percent have been retained by the originating institution. 


\section{Past Lessons and Future Challenges}

The recent rapid growth in housing finance through private mortgages appears grounded on more solid primary and secondary markets than in the past. Private mortgage lending has been steadily increasing since the beginning of 2003, and all expectations are that the trend will continue. The resilience of the new housing finance framework is based on the fact that most new mortgages are inflation-indexed or have fixedpeso rate interest, and the bulk of the origination has taken place through non-deposit taking institutions. In addition, the standardization of mortgage issuance, including SHF's requirements of strict origination practices in terms of underwriting and eligibility criteria, has facilitated access to local funding by mortgage issuers at relatively low rates.

The development of the mortgage bond market with pass-through securities has enabled financial institutions to reduce on-balance sheet risk. In particular, credit, market and maturity mismatch risks are transferred to securitizing vehicles while creating increasingly liquid bond pools in the local capital markets.

\section{A number of infrastructural issues merit close attention to assure the future}

development of secondary mortgage markets. In particular, there is still a need to improve public property registries. These registries are still paper based and not systematized, raising the cost of collateral verification. The role of auditors and credit rating agencies will have to be strengthened to increase their credibility. In many instances, auditors are reportedly able to check only 5 to 10 percent of the titles of a portfolio pool. As recommended in the 2006 FSAP Update, issuers and regulators should consider standards for the inclusion of due diligence firms to review the files of the loans that make up collateral pools. ${ }^{24} 25$

The mortgage-backed securities valuation methodology has to be adapted to the Mexican situation. Although reliance on highly theoretical models is a common problem with the valuation of structured products in general, in the case of Mexico, the problem is compounded due to a lack of mortgage prepayment and default history. SHF has been cognizant of this problem and has sought to develop centralized prepayment and default databases, but these are not yet fully operational.

The absence of a market for lower-rated securities means that the mezzanine or junior tranches of the securitized portfolios are held by the originating institutions. This

\footnotetext{
${ }^{24}$ Technical Note on Housing Finance, prepared for the 2006 FSAP Update (http://wbln0018.worldbank.org/FPS/fsapcountrydb.nsf/FSAPexternalcountryreports?OpenPage\&count=5000).

${ }^{25}$ To illustrate the concern, the FSAP Technical Note on Housing Finance reported that 30 percent of a pool for which SHF was asked to provide mortgage insurance suffered from deficiencies in documentation, ranging from missing credit bureau reports to missing or deficient appraisals. Furthermore, the rating agency did not review any loan files, nor did the institutions that were offering credit enhancements.
} 
situation tends to reduce the risk-diversification value of securitization for those institutions, as they would be retaining the riskiest tranches of the loan portfolios. In turn, this would also imply that the capital relief they can obtain from securitization is limited.

SHF's role as liquidity provider in the RMBS market may represent a contingent fiscal liability under stress events. As a market-maker, SHF has an explicit commitment to buy Borhis, both in the primary and secondary markets, even under stress events. So far, no limit has been explicitly set as to the total amount of Borhis that SHF could buy. In the event of a stress-induced off-load of RMBSs, the SHF would step in to maintain liquidity, leaving the bank vulnerable to market losses. In this context, SHF would benefit from stress test analysis to periodically reassess its level of liquidity. While SHF provisions on the basis of expected losses, reinsures part of the risk from its mortgage insurance products with international insurance corporations, and fully hedges its VSM-UDI liabilities with FOVI, it would be important to assess on a regular basis the institution's liquidity under stress events.

While there is little risk of providing incentives for overbuilding, incentives for substandard house construction may exist. The program of guarantees for construction companies, is aimed at increasing further the amount of funding directed to the housing sector without increasing the associated risk to the lenders. However, the program effectively relieves the lender of the market risk associated with construction activity, and thus provides an incentive to relax quality standards.

Large securitizations by INFONAVIT might complicate RMBS pricing in the market and crowd out private sector issuers. INFONAVIT has been able to issue RMBSs at very compressed spreads relative to the benchmark government bonds. This is somewhat surprising, given that its mortgages are not generally standardized and there are significant problems in valuing the housing constituting its collateral. This highlights, as discussed earlier, the importance that markets assign to implicit public guarantees on the securities. Such guarantees, which constitute a contingent liability for the government, may lead to the crowding-out of other private sector issuers, while obscuring the pricing process in the market.

The recent troubles in the U.S. mortgage market have raised questions about the possibility of a similar replay in Mexico-but there are significant differences between the two markets. The fast pick-up in private mortgages in Mexico was preceded by several years of stagnation and has come from a low level. Furthermore, RMBS remains a very small share of the domestic mortgage market in Mexico, with considerably less serious systemic implications. Finally, the complex securities currently generating volatility in the U.S. markets, such as CDOs, are practically non-existent in the Mexican financial sector.

Nevertheless, the recent troubles in the U.S. mortgage market suggest that the securitization model carries some vulnerabilities. The recent turmoil in financial markets is a reminder that the RMBS valuation process is intrinsically complex, even in countries 
with long historical series and sophisticated technological platforms. In addition, in Mexico, there is a concern that rating agencies have been slow in reviewing the ratings for entities facing financial difficulties (e.g., a recent downgrade was issued only after a default event). The securitization model relies heavily on loan origination and servicing standards. As loans are transferred off-balance sheet, many authors have pointed out the potential for an inherent weakening of the borrower-lender relationship within the securitization vehicle structure (e.g. Davison (2007)). In addition, in the event that securitization model runs into liquidity problems, either because of rising defaults or because of an inability to place new issues, financial institutions may have to buy back their own loans, thus repurchasing the credit risk they had sought to lay off. Finally, the securitizations structured through fideicommisos which are common in Latin America may be even more vulnerable to losses than those structured through SPVs in the U.S., because they do not have their own capital. 
Figure 3. Mexico: Historical Trends in Credit to Housing
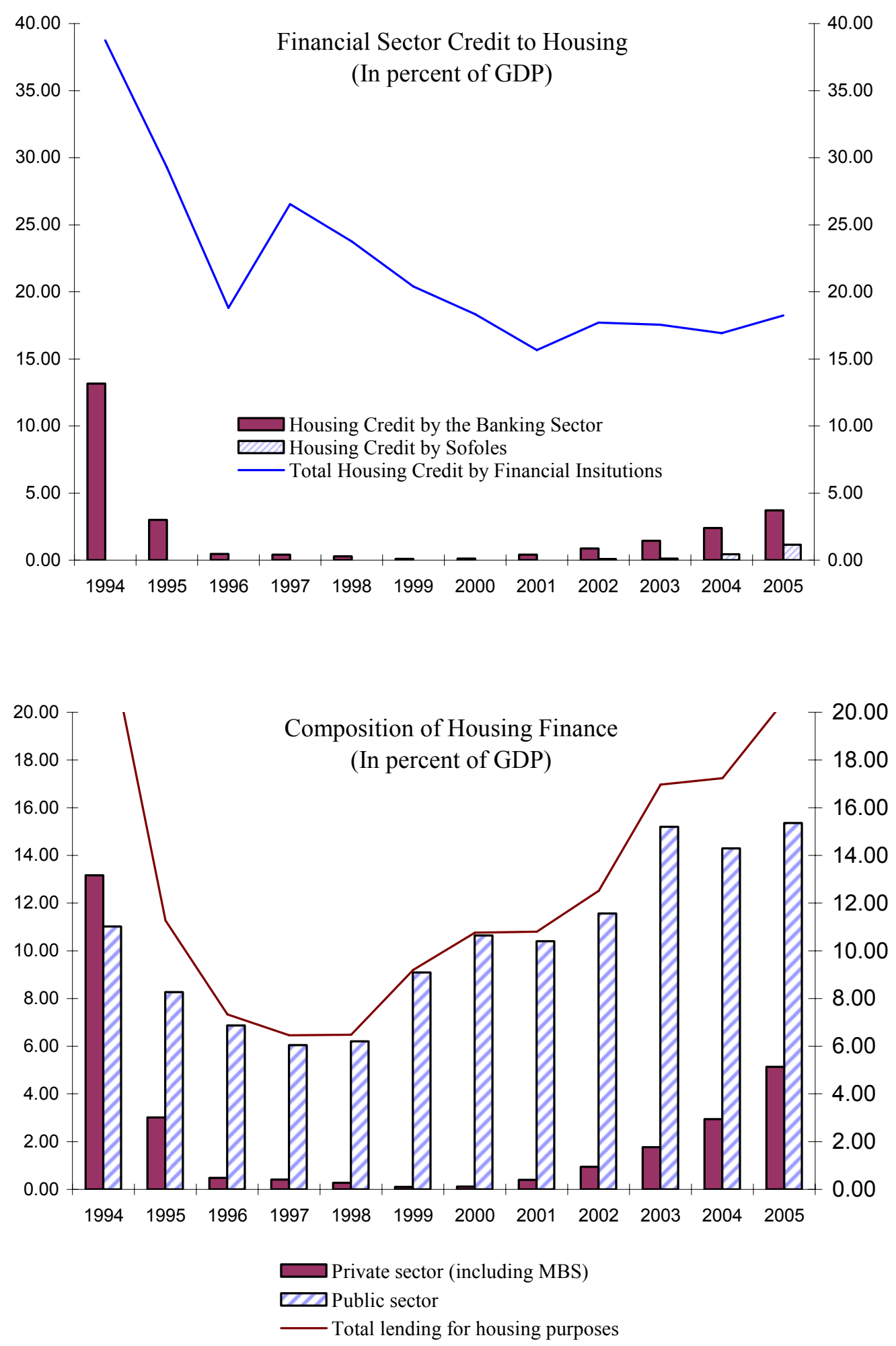

Source: CONAVI, Bank of Mexico, Dealogic and Fund Staff calculations. 
Figure 4. Mexico: Structure of Housing Finance, 2000-2005
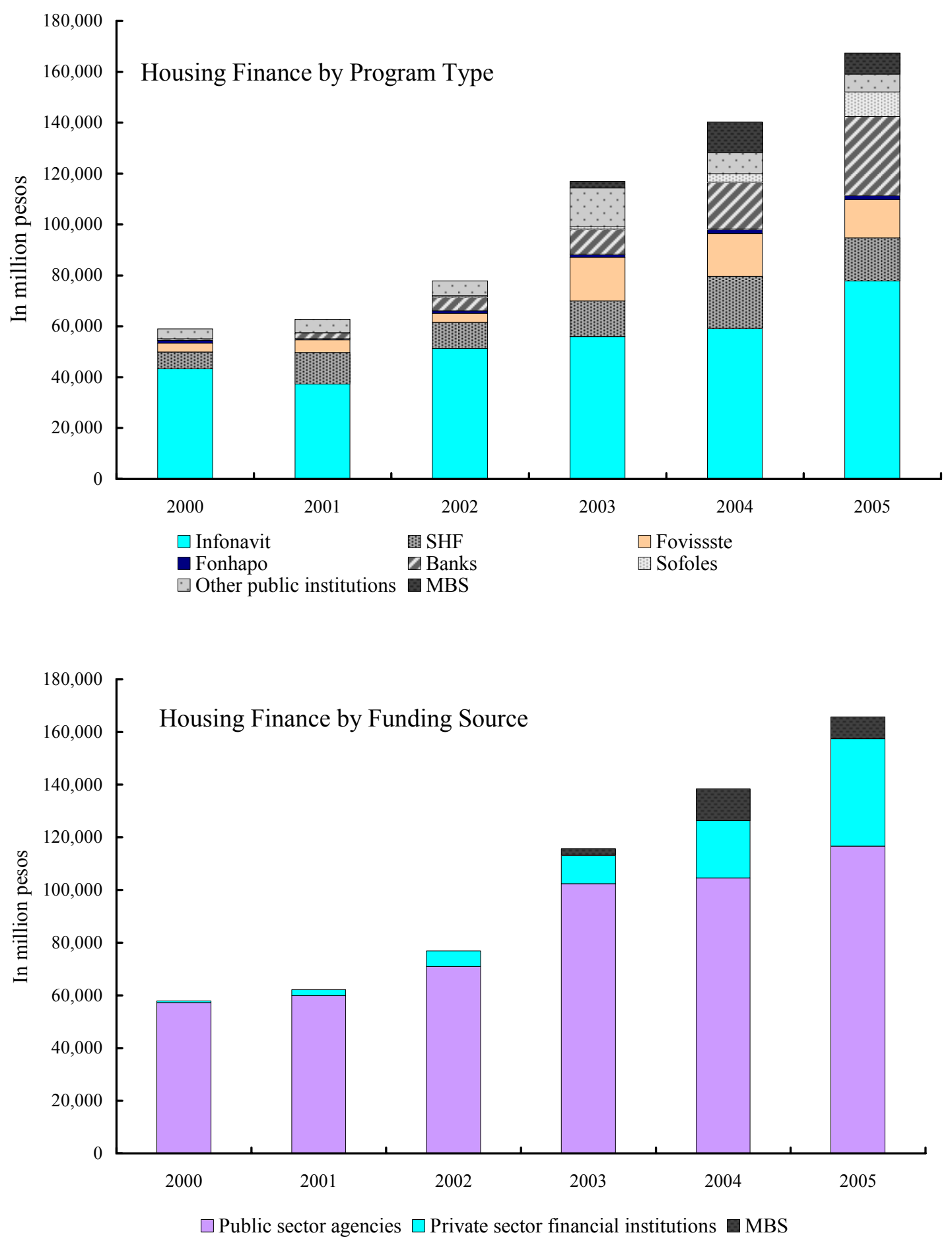

Source: Conavi, Bank of Mexico, Dealogic and Fund Staff calculations. 


\section{REFERENCES}

Barry, C., Castaneda G. and J.B. Lipscomb (1995) "The Structure of Mortgage Markets in Mexico and Prospects for Their Securitization" Journal of Housing Research Vol. 5, n.2, pp. 173-204.

BIS, Committee on the Global Financial System (2006) "Housing Finance in the Global Financial System” CGFS Papers \# 26; January.

Caloca Gonzalez, M. (2006) "Mortgage Backed Securitization: New Legal Developments in Mexico." http://www.natlaw.com/pubs/spmxbk8.htm

CGFS Working Group Report (2006) "Housing Finance in the Global Financial Market" Bank for International Settlements, CGFS Papers 26.

Chiquier, L. O. Hassler and M.J. Lea (2004) "Mortgage Securities in Emerging Markets" World Bank Policy Research WP 3370.

Credit Suisse (2006) “Mexico Mortgage Market” Fixed Income Research. September 26.

Current Housing Situation in Mexico (2005) and (2006) by CIDOC and SHF with support from CONAVI and Harvard University Joint Center for Housing.

Davison, Andrew Davidson (2007) "Six Degrees of Separation” The Pipeline. September.

Frankel, A.; Gyntelberg, J. Kjeldsen, K. and M. Persson M. (2004) “The Danish Mortgage Market,” BIS Quarterly Review, March.

Gwinner, W. (2006), FSAP Update, Mexico, Technical Note on Housing Finance http://wbln0018.worldbank.org/FPS/fsapcountrydb.nsf/FSAPexternalcountryreports? OpenPage\&count $=5000$

Haber, S. (2005) "Banking with and Without Deposit Insurance: Mexico’s Banking Experiments , 1884-2004" Stanford University, Mimeo.

Kjelsen, K. (2004) "Mortgage Credit in the USA and in Denmark" Monetary Review, Danmarks Nationalbank; $2^{\text {nd }}$ Quarter.

Lea, M.J. and S.A. Bernstein (1996) "Housing Finance in an Inflationary Economy: The Experience with Mexico" Journal of Housing Economics 5, pp. 87-104.

Pikering, N. (2000) "The Sofoles: Niche Lending or New Leaders in the Mexican Mortgage Market?" W00-2 Joint Center for Housing Studies, Harvard University.

Rogers, J. and R. Zepeda (2006) "Mexico Looks to Denmark on Mortgage-Backed Securities” Global Banking and Financing Policy Review, Vol. , pp. 123-6.

SHF (2006) “White Paper” http://www.shf.gob.mx/files/pdf/06\%20Portfolio\%20Information.pdf. SHF (2007) “Strategy 2007-2013” http://www.shf.gob.mx/files/pdf/Estrategia\%202007- 2013.pdf. 